\title{
Selection Contractors in E-Tendering Procurement Of Goods And Services Bureau Central Kalimantan Using Analysis Network Process
}

\author{
Citra Amalia ${ }^{1}$ and Djoko Budiyanto Setyohadi ${ }^{2}$ \\ ${ }^{123}$ Magister Teknik Informatika, Universitas Atma Jaya Yogyakarta, Yogyakarta - Indonesia 55281
}

\begin{abstract}
Selection a contractor in e-tendering procurement of goods and service is an routine activity at tenders of Central Kalimantan government. It task is doing the selection against the contractors of e-tendering that offer documents are uploaded on the website of the official Bureau of procurement of goods and services of Central Kalimantan. Selection a contractor is a complicated task because it must be transparently but the problem is the system still lacks proper judgment for not explained about score points for contractors who do not win. System use fall system and not give a thorough explanation about contractors who did not win the tender. This research aims to be able to resolve the problem using Analysis Network Process to select contractor to provide the weight of each of the criteria. The criteria are administrative, price, technical, and prove the qualifications must be completed by each participant contractor who register on e-tendering. The contributin this research serve as a guide for the Bureau of procurement of goods and services and select the contractor in tenders held so a clear assessment and is open to contractors who follow e-tendering held Bureau Procurement of goods and services in Central Kalimantan.
\end{abstract}

Keywords: Procurement; E-tendering, Analysis Network Process, Contractors, Central Kalimantan.

\section{Introduction}

Indonesia have many Imperial construction companies that is as much as over one hundred thousand construction companies in Indonesia. In Indonesia there are 128,570 contractors active nationally. Details of the number of small contractors as much as 108,626 or $85 \%$. The number of big contractors only $2 \%$ or 2,433 contractors and contractor 17,511 medium or $14 \%$ [1].

Procurement Of Goods And Services Bureau in Central Kalimantan handle project tenders procurement of goods and construction working above 200 million rupiah. Projects under the 200 million rupiah is handled directly by the Agency through a direct appointmentrelated contractors. A tender on selection of Bureau of procurement of goods and services through several stages, namely the administrative file selection, selection of technical work, selection of price and selection of proof qualifications. The current bureau system this is a knockout. It is becoming one of the focus of the research is due to leave the system fall used to be an issue that is often on the talk about local contractors in Central Kalimantan since determination of the winners don't pay attention to the weight of each criterion points. In the selection of contractors is less appropriate if using knockout because of not considering the overall score points but only pay attention to the completeness of the file. Bureau of procurement of goods and services formed a team in each tender which held that is composed of a Chairman and two members. The team in charge of conducting the selection against the tender. Contractor selection with four stages, namely administration, technical work, price quotes, and Standard Procurement Documents based on qualifying goods/services the Government Electronically with ETendering (Regulation No. 4 of the year 2015) [2].

In the selection of contractors, the team has the task of deciding the winner of the tender on the basis of predetermined criteria. The team used the knockout in the selection of contractors in Central Kalimantan. In this study the author aims at contributing to the fall of the system into a system of weighting the scoring to be transparent on the selection of contractors. In this study use ANP (Analytic Network Process). The Analytic Network Process (ANP) i.e. selection with several stages, namely determining criteria, weighting, pairwise comparison, eigen vector, test the consistency of the ratio, then rank [3]. The Analytic Network Process (ANP) is a multicriteria theory of measurement used to derive relative priority scales of absolute numbers from

* Corresponding author: citra.chicit@,gmail.com, djoko.bdy@gmail.com 
individual judgments (or from actual measurements relative to a normalized form) that also belong to a fundamental scale of absolute numbers [4].

This research aims to provide theoretical contribution about the ANP with the awarding of the weighting on each criterion because Bureau of procurement of goods and services (BPBJ) Central Kalimantan did not previously use the system weights but knockout so this study into consideration Committee working group decision in determining the winner of the tender for construction in Central Kalimantan.

\section{Literature Review}

\subsection{Analysis Network Process}

According to hosseini [5] The ANP methodology consists of three main steps, namely, pairwise comparisons and local priority vectors, weighted matrix, and super super matrix formation and transformation. ANP is used for the selection of the best strategy in supply chain risk issues.

Stages of the ANP, according to coulter et al [6] is a decision problem, using pairwise comparison, The relative weights or priorities of the elements, Relative local priorities of each element, Additional "files" of elements, Networks of files.

According to jeon et al. [7], the ANP are used in networking cooperation partners. Approach based on the analytic network process (ANP) to rank a set of potential candidates within a multivariate set of attributes systematically. The criteria used are the 25 criteria.

\subsection{Pairwise Comparison}

The use of pairwise comparisons for comparison matrix criteria is a lot of trouble if too many criteria. In addition, the ANP pairwise comparison procedure and subsequent analysis permits the integration of quantitative and qualitative /intangible/ tangible measures into a single overall score for ranking decision alternatives. Finally, the ANP is superior to other forms of multiattribute analysis [8] as well as to choice-based conjoint methods, in that it enables its user to consider interdependencies between and among factors.

\subsection{Consistency Ratio}

According to kabak et al [9] If the value of Consistency Ratio (CR) for the matrix is smaller than $10 \%$, the DMs ' consistency for the evaluations within the matrix is acceptable. If the $\mathrm{CR}$ is equal to or greater than $10 \%$, pairwise comparisons within the matrix must be evaluated again.

\section{Methodology}

Methodology used ANP with the following stages.

1. Study Literatur : Study of the theory of reference related to the topic, namely the method of ANP.
2. Identification Problem : Study of the theory of reference related to the topic IE maMengidentifikasi problem in the topic of research and looking for the best solution in a case study using the method of ANP in the selection of contractors in Central Kalimantan with ANP method.

3. Data Collection : The data obtained is qualitative data, observations, interviews.

4. Tahapan ANP :

- Determine Criteria : Data based on Standard Documents Government procurement of goods/services Electronically with E-are Tendering (Regulation No. 4 of the year 2015)

- Pairwise Comparison : Pairwise comparison is used in decision making for forming the matrix so that the changed data into a ratio

- Eigen Vector

- Test Consistency ratio : The ratio of consistency is done in order to ascertain whether the judgment being entered is accurate and can be used for the calculation of the ANP. According to the rules, consistent comparison matrix only if the value of the CR is less than 0.1 [10].

- Rank

\section{Discussion}

Stages of research using the ANP for selection of contractors in Central Kalimantan.

1. Criteria

Criteria are used in accordance with the standard Procurement documents of goods/services the Government Electronically with E-are Tendering (Regulation No. 4 of the year 2015) published the Agency Procurement Policies Government goods/services, namely administration, technical, pricing, and qualifications. Its administrative HR criteria i.e. completeness of legality of administrative files, technical is a document discussing the technical work, i.e. the price the total price bid contractor against tender qualifications, namely proof of the authenticity of all documents administrative, technical and price review by tim Bureau of procurement of goods and services.

2. Weight of Criteria

The weighting of criteria based on the scale of the ANP saaty as follows:

Table 1. The fundamental scale of absolute numbers (saaty)

\begin{tabular}{|l|l|}
\hline $\begin{array}{l}\text { Intensity of } \\
\text { importance }\end{array}$ & Definition \\
\hline 1 & Equal Importance \\
\hline 2 & Weak or slight \\
\hline 3 & Moderate importance \\
\hline 4 & Moderate plus \\
\hline 5 & Strong importance \\
\hline 6 & Strong plus \\
\hline
\end{tabular}




\begin{tabular}{|l|l|}
\hline 7 & $\begin{array}{l}\text { Very strong or demonstrated } \\
\text { importance }\end{array}$ \\
\hline 8 & Very, very strong \\
\hline 9 & Extreme importance \\
\hline $\begin{array}{l}\text { Reciprocals of } \\
\text { above }\end{array}$ & $\begin{array}{l}\text { If activity i has one of the above non- } \\
\text { zero numbers assigned to it when } \\
\text { compared with i }\end{array}$ \\
\hline
\end{tabular}

Based on the table above then established criteria with weights of interest as follows:

Table 2. criteria

\begin{tabular}{|l|c|c|c|c|}
\hline Criteria & $\begin{array}{c}\text { Adminis- } \\
\text { tration }\end{array}$ & $\begin{array}{c}\text { Techn- } \\
\text { ical }\end{array}$ & Price & Qualification \\
\hline administration & 1 & 0,33 & 0,20 & 0,14 \\
\hline Technical & 3 & 1,00 & 0,60 & 0,43 \\
\hline Price & 5 & 1,67 & 1,00 & 0,71 \\
\hline Qualification & 7 & 2,33 & 1,40 & 1,00 \\
\hline total & 16 & 5,33 & 3,2 & 2,29 \\
\hline
\end{tabular}

Description :

1. Administrative Criteria-Administration (1): just as important as its administrative HR administration

2. Technical Criteria - Administration (3): a little more important than technical administration

3. The criterion of price-administration (5): price is more important than the Administration

4. Qualifying Criteria - Administration (7): qualifying is very important from the administrative

5. Administrative Criteria - technical (1/3): Use the inverse of the technical criteria against administrative inverse for comparison

6. Technical Criteria-technical (1): technical is as important as the technical

7. Price - Technical Criteria (5/3): Use the inverse of the technical criteria for comparison against the price of the inverse

8. Qualifying Criteria - technical (7/3): Use the inverse of the technical criteria against the qualifications for the comparison of the inverse

9. Administrative Criteria - price (1/5): Use the inverse criteria for comparison against the price administrative inverse

10. Technical Criteria - price (3/5): Use the inverse of the technical criteria for comparison against the price of the inverse

11. Price - the price Criterion (1): the price is as important as price

12. Qualifying Criteria - price (7/5): Use the inverse criteria qualifying for comparison against the price of the inverse

13. Administrative Criteria-qualifications (1/7): Use the opposite qualifying criteria against the Administration for comparison of the inverse

14. Technical Criteria - qualifications (3/7): Use the inverse criteria qualifying against technical comparison for the inverse

15. Price Criteria - qualifications (5/7): Use the opposite qualifying criteria for comparison against the price of the inverse

16. Qualifying Criteria - qualifications (1): qualifying as important as qualifying..

\section{Pairwise Comparison}

Pairwise comparison is used in determine the decision to form the matrix so as to change the data into the ratio [11]. Paired comparison matrix mengkalikan i.e. himself against himself as below.

$$
\begin{aligned}
\left|\begin{array}{rrrr}
1 & 0,33 & 0,20 & 0,14 \\
3 & 1,00 & 0,60 & 0,43 \\
5 & 1,67 & 1,00 & 0,71 \\
7 & 2,33 & 1,40 & 1,00
\end{array}\right| \times\left|\begin{array}{rrrr}
1 & 0,33 & 0,20 & 0,14 \\
3 & 1,00 & 0,60 & 0,43 \\
5 & 1,67 & 1,00 & 0,71 \\
7 & 2,33 & 1,40 & 1,00
\end{array}\right| \\
\\
=\left|\begin{array}{rrrr}
\mathbf{4} & \mathbf{1 , 3 3} & \mathbf{0 , 8} & \mathbf{0 , 5 7} \\
\mathbf{1 2} & \mathbf{4} & \mathbf{2 , 4} & \mathbf{1 , 7 1} \\
\mathbf{2 0} & \mathbf{6 , 6 7} & \mathbf{4} & \mathbf{2 , 8 6} \\
\mathbf{2 8} & \mathbf{9 , 3 3} & \mathbf{5 , 6} & \mathbf{4}
\end{array}\right|
\end{aligned}
$$

The result matrix criteria pairwise comparison:

$\left[\begin{array}{cccc}4 & 1,33 & 0,8 & 0,57 \\ 12 & 4 & 2,44 & 1,71 \\ 20 & 6,67 & 4 & 2,06 \\ 28 & 9,33 & 5,6 & 4\end{array}\right]=\begin{gathered}6,70 \\ 20,11 \\ 33,52 \\ \frac{46,98 *}{107,28}\end{gathered}$

From the matrix above, eigen vector can be determined, lambda consistensi index and maximum, and consistensi ratio. Eigen vector values obtained from the division between the first line against the number of values in the first column of the second row in Add and divide the amount of the value of the second column and so on up to four columns.

The number of the first column of the matrix:

$4+12+20+28=64$

The amount of the second column of the matrix: $1,33+4+6,67+9,33=21,33$

The number of the third column of the matrix: $0,8+2,44+4+5,6=12,8$

The number of the fourth column of the matrix: $0,57+1,71+2,86+4=91,4$

\section{Eigen Vector}

Next do the calculations to find the following eigen vector.

Eigen vector lines 1:

$$
\frac{\left(\frac{4}{84}+\frac{1,88}{21.88}+\frac{0,8}{12,8}+\frac{0,57}{91,4}\right)}{4}=0,0625
$$

Eigen vector line 2 :

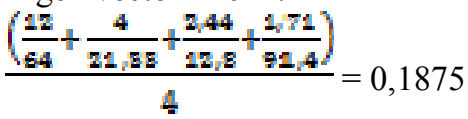

Eigen vector line 3 :

$$
\frac{\left(\frac{20}{64}+\frac{6,67}{21,88}+\frac{4}{12,8}+\frac{2,86}{91,4}\right)}{4}=0,3125
$$

Eigen vector line 4 :

$$
\frac{\left(\frac{20}{84}+\frac{9,82}{21,88}+\frac{5,6}{12,8}+\frac{4}{91,4}\right)}{4}=0,4375
$$

Table 3. The value of the Eigen Vector Criteria against the matrix of pairwise comparison

\begin{tabular}{|r|c|r|r|r|r|}
\hline & $\mathbf{A}$ & $\mathbf{T}$ & $\mathbf{H}$ & $\mathbf{K}$ & eVECTOR \\
\hline $\mathbf{A}$ & 1 & 0,33 & 0,20 & 0,14 & 0,0625 \\
\hline $\mathbf{T}$ & 3 & 1,00 & 0,60 & 0,43 & 0,1875 \\
\hline $\mathbf{H}$ & 5 & 1,67 & 1,00 & 0,71 & 0,3125 \\
\hline $\mathbf{K}$ & 7 & 2,33 & 1,40 & 1,00 & 0,4375 \\
\hline jumlah & 16 & 5,33 & 3,2 & 2,29 & $\mathbf{1}$ \\
\hline
\end{tabular}

Description : 


$$
\begin{aligned}
& \mathrm{A}=\text { Administrative } \\
& \mathrm{T}=\text { Technical } \\
& \mathrm{H}=\text { Price } \\
& \mathrm{K}=\text { Qualification }
\end{aligned}
$$

\section{Test Consistency Ratio}

Next is calculating the maximum lamda as follows:

$\lambda$ maks : $(16 \times 0,0625)+(5,33 \times 0,1875)+$

$(3,2 \times 0,3125)+(2,29 \times 0,4375)=4$

Consistency index $=\frac{4-4}{4-1}=0$ as in equation

Where CI:

$$
C I=\frac{\lambda_{m a k 3}-n}{n-1}
$$

On matrix consistency, practically $\lambda_{\text {maks }}=n$, While not every variation of the matrix will bring changes to the value of $\lambda_{\text {maks }}$. Deviation $\lambda_{\text {maks }}$ from $\mathrm{n}$ is a parameter of the Consistency Index (CI).

Description:

$\mathrm{CI}=$ Consistency Index

$\lambda_{\text {maks }}=$ maks eigen value

$\mathrm{n}=$ the number of elements that are further than did the calculation equation with the formula $\mathrm{CR}$ :

$$
C R=\frac{C I}{R I}
$$

Description:

$\mathrm{CR}=$ Consistency Ratio

$\mathrm{CI}=$ Consistency Index

$\mathrm{RI}=$ Random Index

Table 4. Random Index

\begin{tabular}{|c|c|c|c|c|c|c|c|c|c|c|}
\hline $\begin{array}{c}\text { Ord } \\
\text { er }\end{array}$ & 1 & 2 & 3 & 4 & 5 & 6 & 7 & 8 & 9 & 10 \\
\hline R.I. & 0 & 0 & 0.5 & 0.8 & 1.1 & 1.2 & 1.3 & 1.4 & 1.4 & 1.4 \\
& 2 & 9 & 1 & 5 & 5 & 0 & 5 & 9 \\
\hline
\end{tabular}

The ratio of the consistency or CR obtained using equation 2.2

The value of the RI for $n=4$ is 0.89 can be seen in table 2.2

$$
\mathrm{CR}=\mathrm{CI} / \mathrm{RI}=0 / 0,89=0
$$

The above value is consistent because $\mathrm{CR} \leq 0.1$. If the value of $\mathrm{CR}>0.1$ then not consistent or unqualified and subsequent decision matrix should be repeated until the $\mathrm{CR}$ values consistently or qualify the consistency.

6. Determine value alternative

- Value alternative

Table 5. contractor appraisal information

\begin{tabular}{|l|l|}
\hline Value & description \\
\hline $0-50$ & Not Good \\
\hline $51-69$ & Enough \\
\hline $70-84$ & Good \\
\hline $85-100$ & Very good \\
\hline
\end{tabular}

The value of the specified range, the data range that is created into a scale of interests saaty, can be seen in the following table: Table 6. Range alternatif comparison

\begin{tabular}{|l|l|}
\hline Range & Value of interest \\
\hline Very good-very good & 1 \\
\hline Very good - good & 3 \\
\hline Very good - enought & 5 \\
\hline Very good - not good & 7 \\
\hline good - enought & 2 \\
\hline
\end{tabular}

\begin{tabular}{|l|l|}
\hline good - not good & 4 \\
\hline enought - not good & 2 \\
\hline
\end{tabular}

Here is an example of the case selection in Central Kalimantan using method ANP.

Table 7. Alternative

\begin{tabular}{|c|c|c|c|}
\hline Alternative & PT. X & PT. Y & PT. Z \\
\hline A & 100 & 100 & 100 \\
\hline T & 75 & 90 & 50 \\
\hline H & 80 & 70 & 60 \\
\hline K & 100 & 100 & 100 \\
\hline
\end{tabular}

Pairwise comparison done between subsequent alternative against each of the criteria and looking for the value of the eigeh vector.

Table 8. Paired Comparison Matrix of alternatives to the Administration's criteria

\begin{tabular}{|c|c|c|c|c|}
\hline A & $\begin{array}{c}\text { PT. } \\
\text { X }\end{array}$ & PT.Y & $\begin{array}{c}\text { PT. } \\
\mathbf{Z}\end{array}$ & eVECTOR \\
\hline PT. X & 1 & 1 & 1 & 0,333333 \\
\hline PT. Y & 1 & 1 & 1 & 0,333333 \\
\hline PT. Z & 1 & 1 & 1 & 0,333333 \\
\hline Jumlah & 3 & 3 & 3 & $\mathbf{1}$ \\
\hline
\end{tabular}

Description:

A : Administration

1. PT. X - PT. X (100-100): a comparison of alternative range is from 1 (very good- very good)

2. PT. Y - PT. X (100-100): a comparison of alternative range is from 1 (very good- very good)

3. PT. Z - PT. X (100-100): a comparison of alternative range is from 1 (very good- very good)

4. PT. X - PT. Y (100-100): a comparison of alternative range is from 1 (very good- very good)

5. PT. Y - PT. Y (100-100): a comparison of alternative range is from 1 (very good- very good)

6. PT. Z - PT. Y (100-100): a comparison of alternative range is from 1 (very good- very good)

7. PT. X - PT. Z (100-100): a comparison of alternative range is from 1 (very good- very good)

8. PT. Y-PT. Z (100-100): a comparison of alternative range is from 1 (very good- very good)

9. PT. Z - PT. Z (100-100): a comparison of alternative range is from 1 (very good- very good).

To get the value of the eigen vector then performed the following stages:
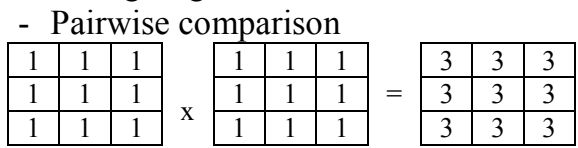

Paired comparison results matrix criteria:

$\left[\begin{array}{lll}3 & 3 & 3 \\ 3 & 3 & 3 \\ 3 & 3 & 3\end{array}\right]=\frac{9}{9}$ 
From the matrix above, eigen vector can be determined, lambda consistensi index and maximum, and consistensi ratio. Eigen vector values obtained from the division between the first line against the number of values in the first column of the second row in Add and divide the amount of the value of the second column and so on up to the third column.

The first column of the matrix sum of: $3+3+3=9$

The second column of the matrix sum of: $3+3+3=9$

The third column of the matrix sum of: $3+3+3=9$

Next do the calculations to find the following eigen vector.

Eigen vector line $1: \frac{\left(\frac{5}{8}+\frac{8}{5}+\frac{8}{3}\right)}{3}=0,33$

Eigen vector line $2: \frac{\left(\frac{3}{3}+\frac{3}{3}+\frac{5}{3}\right)}{3}=0,33$

Eigen vector line $-3: \frac{\left(\frac{8}{9}+\frac{8}{9}+\frac{8}{9}\right)}{3}=0,33$

Criteria for the $\mathrm{T}, \mathrm{H}$, and $\mathrm{K}$ using the same calculation. Below follows a table of the results of the calculation criteria for the $\mathrm{T}, \mathrm{H}$, and $\mathrm{K}$.

Table 9. Pairwise Comparison Matrix of alternatives for Technical criteria

\begin{tabular}{|c|c|c|c|c|}
\hline T & PT. X & PT. Y & PT. Z & eVector \\
\hline PT. X & 1 & 0,33 & 4 & 0,26 \\
\hline PT. Y & 3 & 1 & 7 & 0,66 \\
\hline PT. Z & 0,25 & 0,14 & 1 & 0,08 \\
\hline
\end{tabular}

Table 10. Pairwise Comparison Matrix of alternatives to the criteria Price

\begin{tabular}{|c|c|c|c|c|}
\hline T & PT. X & PT. Y & PT. Z & eVector \\
\hline PT. X & 1 & 1 & 2 & 0,40 \\
\hline PT. Y & 1 & 1 & 2 & 0,40 \\
\hline PT. $\mathbf{Z}$ & 0,5 & 0,50 & 1 & 0,20 \\
\hline
\end{tabular}

Table 11. Pairwise Comparison Matrix of alternatives for Qualifications criteria

\begin{tabular}{|c|l|l|l|c|}
\hline T & PT. X & PT. Y & PT. Z & eVector \\
\hline PT. X & 1 & 1 & 1 & 0,33 \\
\hline PT. Y & 1 & 1 & 1 & 0,33 \\
\hline PT. Z & 1 & 1 & 1 & 0,33 \\
\hline
\end{tabular}

\section{Rank}

Calculation based on entirely then it can be determined the ranking of the contractor as follows.

Table 12. Rank

\begin{tabular}{|c|c|c|c|c|c|c|c|}
\hline $\begin{array}{c}\text { Altern } \\
\text { ative }\end{array}$ & $\mathbf{A}$ & $\mathbf{T}$ & $\mathbf{H}$ & $\mathbf{K}$ & $\begin{array}{c}\text { TOT } \\
\text { AL }\end{array}$ & $\begin{array}{c}\text { NOR } \\
\text { MA } \\
\text { L }\end{array}$ & $\begin{array}{c}\text { RAN } \\
\text { K }\end{array}$ \\
\hline PT. X & 0,33 & 0,26 & 0,4 & 0,33 & 1,33 & 0,33 & 2 \\
\hline PT. Y & 0,33 & 0,66 & 0,4 & 0,33 & 1,73 & 0,43 & 1 \\
\hline PT. Z & 0,33 & 0,08 & 0,2 & 0,33 & 0,94 & 0,24 & 3 \\
\hline
\end{tabular}

\section{Conclusion}

In this research it can be concluded that for the selection of contractors in Central Kalimantan with the method of Analysis Network Process is with the stages determines the criteria first, determine the value of the criteria, then it is doing Comparative Matrix pairs and then the results matrix consistency tests conducted trials to prove that the data used can be used or not, if the value consistency less than 0.1 then the data is consistent and can proceed next step determine the value of the eigen vector in each criteria. Alternative input that is done in the next 3 contractor PT X, Y, and $\mathrm{Z}$ values and are given more weight in accordance with the scale of fundamental values and calculations done saaty eigen vector on each alternative against the criteria. After all the stages already done then the next stage is done rank alternative. The highest rank results will be the contractors. Phases of Network Analysis Process used is to specify criteria based on qualitative data from the Bureau of procurement of goods and services.

\section{References}

1. Widiyanto, D. (2017). Proyek Konstruksi di Indonesia Masih Didominasi Kontraktor Besar. [online] www.krjogja.com. Available at: http://krjogja.com/web/news/read/27208/Proyek_Konstru ksi_di_Indonesia_Masih_Didominasi_Kontraktor_Besar [Accessed 12 Jul. 2018].

2. inaproc.lkpp.go.id. (2013). Standar Dokumen Pengadaan Barang/Jasa Pemerintah Secara Elektronik Dengan ETendering (Perpres No. 4 Tahun 2015). [online] Available at: $\quad$ https://inaproc.lkpp.go.id/v3/public/sdp/sdp.htm [Accessed 13 Jul. 2018].

3. H. Alidrisi, "An ANP-based multi criteria decision making model for supplier selection," in 2014 IEEE International Conference on Industrial Engineering and Engineering Management, 2014, pp. 585-588.

4. T. L. Saaty, "Fundamentals of the analytic network process - Dependence and feedback in decision-making with a single network," J. Syst. Sci. Syst. Eng., vol. 13, no. 2, pp. 129-157, 2004.

5. Hosseini, L., Tavakkoli-Moghaddam, R., Vahdani, B., Mousavi, S.M. and Kia, R., 2013. Using the Analytical Network Process to Select the Best Strategy for Reducing Risks in a Supply Chain. Journal of Engineering, [online] 2013, pp.1-9. Available at: $<$ http://dx.doi.org/10.1155/2013/375628>.

6. Coulter, K. and Sarkis, J. (2006). An Application of the Analytic Network Process to the Advertising Media Budget Allocation Decision. International Journal on Media Management, [online] 8(4), pp.164-172. Available at:

http://journals.sfu.ca/mediajournal/index.php/jmm/article/ download/42/244 [Accessed 12 Jul. 2018].

7. Jeon, J., Kim, J., Park, Y. and Lee, H., 2016. An analytic network process approach to partner selection for acquisition and development. Technology Analysis \& Strategic Management, [online] 29(7), pp.790-803. Available $<$ http://dx.doi.org/10.1080/09537325.2016.1241873>.

8. Saaty, R.W., 1987. The analytic hierarchy process-what it is and how it is used. Mathematical Modelling, [online] 9(3-5), pp.161-176. Available at: $<$ http://dx.doi.org/10.1016/0270-0255(87)90473-8>.

9. Kabak, Mt., Dağdeviren M., 2017. A hybrid approach based on ANP and grey relational analysis for machine selection. Tehnicki vjesnik - Technical Gazette, [online] 24(Supplement 1). Available at: $<\mathrm{http} / / /$ dx.doi.org/10.17559/TV-20141123105333>.

10. L. N. Son, "Consistency Test in ANP Method with Group Judgment Under Intuitionistic Fuzzy Environment," Int. J. Soft Comput. Eng., no. 3, pp. 2231-2307, 2014.

11. H. Deng, "Multicriteria analysis with fuzzy pairwise comparison," Int. J. Approx. Reason., vol. 21, no. 3, pp. 215-231, 1999. 